\title{
Characterization and bacterial-binding activity of a novel $C$-type lectin from the red-spotted grouper, Epinephelus akaara
}

\author{
Z.W. Zhang ${ }^{1,2}$, X.F. Shi ${ }^{1}$, M. Qu ${ }^{1}$ and S.X. Ding ${ }^{1}$ \\ ${ }^{1}$ State Key Laboratory of Marine Environmental Science, \\ Xiamen University, Xiamen, Fujian, China \\ ${ }^{2}$ Fishery Research Institute of Shanghai, Shanghai, China \\ Corresponding author: S.X. Ding \\ E-mail: sxding@xmu.edu.cn
}

Genet. Mol. Res. 11 (3): 2958-2971 (2012)

Received September 27, 2011

Accepted January 30, 2012

Published May 11, 2012

DOI http://dx.doi.org/10.4238/2012.May.11.1

\begin{abstract}
Because of their specific binding to carbohydrates, lectins play a crucial role in pathogen recognition and clearance in vertebrate animals. Previously, only two types of collectins had been isolated from bony fish: mannan-binding lectin (MBL) and galactosebinding lectin (GalBL). We sequenced a novel collectin (designated EALec1) from the red-spotted grouper, Epinephelus akaara. The gene structure of EALecl and the alignment of the carbohydrate recognition domain of the three collectins demonstrated that EALec 1 is a new type of collectin derived from MBL. We examined the expression pattern of the EALec1 transcripts in 12 tissues of the red-spotted grouper. The EALecl gene was found to have multiple copies; their transcripts were detected in all 12 tissues. EALecl was also recombined and expressed in Escherichia coli to investigate its immune functions and carbohydrate-binding characterization. We concluded that EALec1 belongs to the mannan-binding lectin group, despite its different $\mathrm{Ca}^{2+}$-dependent sites in the carbohydrate recognition domain, and that it is involved in the recognition and
\end{abstract}


clearance of invaders in the red-spotted grouper.

Key words: Epinephelus akaara; C-type Lectin; Genomic structure; mRNA expression; Recombinant expression; Bacterial agglutination

\section{INTRODUCTION}

The vertebrate immune system comprises two mechanisms: the innate and the adaptive defense mechanisms (Schluter et al., 1997; Ellis, 2001; Pancer and Cooper, 2006). As primitive vertebrates, fish likely obtained their adaptive immunity in ancient evolutionary history (Carroll and Prodeus, 1998). The adaptive immune defense in fish has more constraints than in endothermic vertebrates because of its temperature-dependence, limited antibody repertories, affinity maturation and relatively slow response (Janeway and Travers, 1997; Magnadottir, 2006). Thus, innate immunity is considered to be an important defense system against infection in fish (Medzhitov and Janeway, 2000; Whyte, 2007).

The complement system is a crucial component in the innate immunity of teleost fish (Walport, 2000; Boshra et al., 2006). This system can be activated through three separate pathways: the classical pathway (i.e., the C1q pathway), the alternative pathway, and the lectin pathway (Fujita et al., 2004a; Boshra et al., 2006). The latter pathway functions by binding pathogens to two distinct groups of lectins, mannan-binding lectin (MBL) and ficolins, with which MBL-associated serine proteases (MASPs) associate to activate C4, C2 and C3 (Endo et al., 2003; Dodds and Matsushita, 2007; Gaboriaud et al., 2007). The MBL and ficolins have three similar domains: a cysteine-rich $\mathrm{N}$-terminal region, a collagenous region characterized by Gly-X-Y repeats ( $\mathrm{X}$ and $\mathrm{Y}$ stand for any amino acids) (Dodds and Matsushita, 2007), and a neck region. The major differences between them include fewer repeats of Gly-X-Y within ficolin and a fibrinogen-like domain within the C-terminal region of ficolin (Matsushita and Fujita, 2002; Atkinson et al., 2004; Nakao et al., 2006; Runza et al., 2008).

As a component of innate immunity capable of activating complement reactions by the lectin pathway (Zapata et al., 1997; Nonaka and Smith, 2000), the MBL was first discovered in human liver (Miller et al., 1968). Recently, an MBL-like lectin, the glucose-binding lectin (GBL), was isolated from ascidians (genus Urochordata) (Sekine et al., 2001; Endo et al., 2006), which have been identified as the most primitive species with a lectin pathway (Fujita et al., 2004b; Endo et al., 2006). In comparison to the vertebrate MBL, the GBL lacks a collagen region but has an identical tripeptide-binding motif, Glu-Pro-Asn (EPN type), in its carbohydrate recognition domain (CRD). The GBL can bind to MASPs and then activate C3/C4-like TEP. Thus, the GBL is considered to be a prototype of the MBL in an early evolutionary stage (Fujita et al., 2004b; Dodds and Matsushita, 2007). The lamprey is the most primitive animal found to possess the MBL (Takahashi et al., 2006; Dodds and Matsushita, 2007). Two types of the MBL group have been characterized in the bony fish: one has a QPD-type galactose-binding CRD (with Gln-Pro-Asp motif) and is designated GalBL, and the other has an EPN-type mannose-binding CRD and is designated MBL (Vitved et al., 2000; Nakao et al., 2006; Jackson et al., 2007). Previous studies have shown that GalBL was probably mutated from an MBL extra copy and has since acquired galactose-binding capability (Nonaka and Smith, 2000).

In a previous study, we isolated a complete lectin cDNA sequence from the red-spotted grouper, Epinephelus akaara, a valuable commercial fish in southern China (Heemstra and Ran- 
dall, 1993). This locus possesses all of the distinct characteristics of a collectin, yet has an EPDtype CRD (with Glu-Pro-Asp motif) (manuscript submitted). Here, we designated it EALec1. Although a lectin with the same carbohydrate recognition sites has been isolated from the Japanese flounder (Kondo et al., 2007), an analysis of the protein domain features showed that the protein does not have a collagenous region characterized by Gly-X-Y repeats, and thus does not belong to the collectin group (Thiel, 2007). EALec1 can be regarded as a novel collectin that was first identified in the bony fish. To study the evolution of EALec1, we sequenced its genome structure and analyzed its expression pattern in different tissues using single-strand conformation polymorphism (SSCP) analysis and the qRT-PCR technique. The bacterial agglutination activity and carbohydrate-binding specificity of the recombinant EALec1 protein were also investigated to understand the roles of EALec1 in the immune responses of the red-spotted grouper.

\section{MATERIAL AND METHODS}

\section{Material}

One-year-old specimens of E. akaara, with a fresh weight of about $400 \mathrm{~g}$, were collected from a local market in Xiamen, China, and were maintained in filtered seawater for 1 week before processing.

Three bacterial strains were used in this study. Staphylococcus aureus Rosenbach and Bacillus subtilis were supplied by the Institute of Microbiology at the Chinese Academy of Sciences, and Vibrio harveyi was isolated in our laboratory (Xu et al., 2009).

All primers used in this study (Table 1) were synthesized at Invitrogen (Shanghai, China).

\section{Cloning of the full-length genomic sequence of the EALec1 gene}

Based on the complete cDNA sequence of EALecl (NCBI accession No. FG 392023), isolated from E. akaara in our laboratory, the specific PCR primers LectinD1F and LectinD1R (Table 1) were designed to amplify the genomic sequence of the EALecl gene. Extraction of genomic DNA from the muscle of E. akaara was performed using the Invisorb Spin Tissue Mini kit (Invitek, Germany). PCR was carried out with one denaturation step of $5 \mathrm{~min}$ at $94^{\circ} \mathrm{C}, 32$ cycles of $94^{\circ} \mathrm{C}$ for $30 \mathrm{~s}, 55^{\circ} \mathrm{C}$ for $30 \mathrm{~s}$ and $72^{\circ} \mathrm{C}$ for $3 \mathrm{~min}$, and a final extension at $72^{\circ} \mathrm{C}$ for $5 \mathrm{~min}$. The PCR products were gel-purified using the QIAEXII Gel Extraction kit (Qiagen, USA) and cloned into the pMD18-T simple vector (TaKaRa, Japan). They were then transformed into competent cells of Escherichia coli JM109. The positive clones were sequenced at Invitrogen.

\section{Expression detection of EALec1 in different tissues}

The mRNA expression pattern of EALec1 was determined in the different tissues using the qRT-PCR and SSCP techniques. Total RNA of the tissues, including blood, ovary, liver, spleen, muscle, gill, head kidney, intestine, stomach, fin, heart, and brain, was extracted using Trizol (Invitrogen, USA) in accordance with manufacturer instructions. After treatment with RNase-free DNase (Qiagen), $1 \mu \mathrm{g}$ RNA from each tissue was used for cDNA synthesis following the manual for Promega M-MLV use. RT-PCR and real-time RT-PCR were then performed using the two specific primers (LectinF197 and LectinR599) designed from the EALec1 cod- 
ing sequence (Table 1). A 400-bp fragment of the EALec1 sequence was amplified. In parallel, a 300-bp fragment of the b-actin sequence was also amplified to serve as an internal control of RT-PCR with the primers actinF and actinR (Table 1). The PCR procedure involved one cycle of $94^{\circ} \mathrm{C}$ for $2 \mathrm{~min}$ and 30 cycles (or 28 cycles for b-actin) of $94^{\circ} \mathrm{C}$ for $30 \mathrm{~s}, 55^{\circ} \mathrm{C}$ for $30 \mathrm{~s}$ and $72^{\circ} \mathrm{C}$ for $30 \mathrm{~s}$, with a final extension of $72^{\circ} \mathrm{C}$ for $5 \mathrm{~min}$.

\begin{tabular}{ll}
\multicolumn{1}{c}{ Table 1. The oligonucleotide primers used in these experiments. } \\
\hline Primer name & Sequence \\
\hline LectinF & 5'-ACTTCAGCCATATGCCTGCAGGTCGACG-3' \\
LectinR & 5'-CTCGAATTCACTT GAATGGGGT-3' \\
LectinD1F & 5'-ATGAACCTCATCAAAAAGGAA-3' \\
LectinD1R & 5'-TCACTTGAATGGGGTAGGCGCC-3' \\
LECTINF197 & 5'-TGAGACTAAACTTGTTGGAGGAT-3' \\
LECTINR599 & 5'-GCCTGGCT GTTGTCTGGCTCTGT-3' \\
actinF & 5'-AAGCCAACAGGGAGAAGATGAC-3' \\
actinR & 5'-GCCAGGTCTTCACCGCCGTCATGGT-3' \\
Oligo-dT-RA & 5'-AAGCAGTGGTATCAACGCAGAGTGTAC(T) ${ }_{25}$ VN-3' $^{\prime}$ \\
\hline
\end{tabular}

Before SSCP analysis, $2 \mu \mathrm{L}$ RT-PCR product were mixed with $2 \mu \mathrm{L}$ denaturing buffer $(95 \%$ formamide, $0.1 \%$ bromophenol blue, $0.1 \%$ xylene cyanole FF, 1 mM EDTA, and 10 $\mathrm{mM} \mathrm{NaOH})$. The samples were denatured at $95^{\circ} \mathrm{C}$ for $5 \mathrm{~min}$ and immediately cooled on ice for $2 \mathrm{~min}$ before they were separated by $1-\mathrm{mm} 8 \%$ native polyacrylamide gel electrophoresis (PAGE). Electrophoresis was performed on 1X TBE buffer under optimized conditions (200 $\mathrm{V}$ for $5 \mathrm{~h}$ at $4^{\circ} \mathrm{C}$ ). Prior to silver staining, the gels were fixed with $10 \%$ acetic acid for 20 min, rinsed twice in deionized water and soaked in $0.01 \mathrm{M}$ silver nitrate for $30 \mathrm{~min}$. The gels were then rinsed twice in deionized water, and reduction was carried out in a solution of 0.75 $\mathrm{M}$ sodium hydroxide and $0.085 \mathrm{M}$ formaldehyde until the DNA bands were clearly visible (maximum 10-15 min). The reaction was stopped by transferring the gels to $0.07 \mathrm{M}$ sodium carbonate for $30 \mathrm{~min}$. The different DNA bands were purified and cloned into the pMD18-T simple vector (Takara), and then transformed into the competent cells of E. coli JM109. Three positive clones of each band were sequenced at Invitrogen.

Real-time RT-PCR was performed on a Rotor-Gene RG3000 (Corbett Research, Australia) using a SYBR Green 2-Supermix kit (Applied Biosystems, USA). PCR was carried out with one cycle of $94^{\circ} \mathrm{C}$ for $2 \mathrm{~min}$ and 40 cycles of $94^{\circ} \mathrm{C}$ for $15 \mathrm{~s}, 55^{\circ} \mathrm{C}$ for $20 \mathrm{~s}$ and $72^{\circ} \mathrm{C}$ for 30 $\mathrm{s}$. The fluorescence output for each cycle was measured and recorded at the end of the entire run. Cycle threshold values were calculated using the Rotor-Gene-6171 software and were converted into an equivalent target amount (ETA) using the established statistical standard curve. The expression levels of EALec1 were with respect to b-actin as previously described.

\section{Protein expression and purification}

The protein-coding region of the EALecl gene was amplified using the specific PCR primers LectinF and LectinR from the cDNA of the liver. To enable cloning, a NodeI site was added to the 5'-end of LectinF and an EcoRI site to the 5'-end of LectinR. The RT reaction began with a 5 min denaturation step at $95^{\circ} \mathrm{C}$, followed by 32 cycles of 1 min at $95^{\circ} \mathrm{C}, 1 \mathrm{~min}$ at $52^{\circ} \mathrm{C}$, and 1 min at $72^{\circ} \mathrm{C}$, with a final extension at $72^{\circ} \mathrm{C}$ for $5 \mathrm{~min}$. After running on a $1 \%$ agarose gel, the PCR fragment was gel-purified and completely digested with the restriction enzymes NodeI and EcoRI 
(NEB, USA) and then cloned into the NodeI / EcoRI sites of the expression vector pET28(A). The recombinant plasmid (pET-28(A)-EALec-1) was transformed into E. coli BL21(DE3)-pLysS.32a. The positive clones were screened using PCR with the specific primers LectinF and LectinR. The recombinant plasmid was extracted from the positive clones and digested with NodeI and EcoRI, then sequenced to confirm the exact insert. The positive clone was named EALec- 12 .

EALec-12 was added to $100 \mathrm{~mL}$ Luria broth solution with $50 \mu \mathrm{g} / \mathrm{mL}$ kanamycin. The solution was shaken overnight at $37^{\circ} \mathrm{C}$. Next, $10 \mathrm{~mL}$ starter culture were added, and the solution was incubated for about $2 \mathrm{~h}$ until the density approached $\mathrm{OD}_{600}=0.2-0.3$. The expression of the protein was induced by adding $0.2 \mathrm{mM}$ isopropyl-D-thiogalactopyranoside (IPTG). After $4 \mathrm{~h}$ of induction at $37^{\circ} \mathrm{C}$, the cells were harvested by centrifugation at $3500 \mathrm{~g}$ for $2 \mathrm{~min}$ at $4^{\circ} \mathrm{C}$. Subsequently, all of the cells were stored in liquid nitrogen overnight. After thawing, the bacterial cells were resuspended in a $40 \mathrm{~mL}$ column buffer and sonicated in an ice-water bath. After centrifugation at $12,000 \mathrm{~g}$ for $30 \mathrm{~min}$ at $4^{\circ} \mathrm{C}$, the supernatant was purified with a Ni-NTA Agarose column (Qiagen), and the isolated protein was used for the activity assay. The purified recombinant EALec was subjected to $12 \%$ SDS-PAGE at $200 \mathrm{~V}$ for $3 \mathrm{~h}$. The protein separation was visualized by staining with Coomassie brilliant blue R-250 (Sigma, USA). Molecular weight protein standards were used to determine the target protein size.

\section{Bacterial agglutination and bacterial agglutination inhibition assay}

The Gram-negative pathogenic $V$. harveyi and Gram-positive non-pathogenic $S$. aureus Rosenbach and B. subtilis were incubated in $100 \mathrm{~mL}$ LB separately. Subsequently, they were harvested by centrifugation at $3500 \mathrm{~g}$ for $2 \mathrm{~min}$ at $4^{\circ} \mathrm{C}$, suspended in a Tris-buffered saline (TBS) $(50 \mathrm{mM}$ Tris- $\mathrm{HCl}, 100 \mathrm{mM} \mathrm{NaCl}, \mathrm{pH} 7.5)$ at $\mathrm{OD}=0.5$, and then stored at $4^{\circ} \mathrm{C}$ before further processing. The purified protein was desalted via centrifugation in a Millipore Amicon Ultra (Millipore, USA) at $7000 \mathrm{~g}$ for $40 \mathrm{~min}$. The concentration was then adjusted to $100 \mu \mathrm{g} / \mathrm{mL}$ using TBS1 (100 mM Tris, $1 \mathrm{mM} \mathrm{NaCl}, \mathrm{pH}$ 7.5). The protein concentration was measured using the Bradford method (Thiel, 2007). An aliquot of $8 \mu \mathrm{L}$ bacterial suspension was added to $1 \mu \mathrm{L}$ recombinant EALec. TBS2 (100 mM Tris, $\left.1 \mathrm{mM} \mathrm{NaCl}, 100 \mathrm{mM} \mathrm{CaCl}_{2}, \mathrm{pH} 7.5\right)$ was used to adjust the concentration of $\mathrm{Ca}^{2+}$ to $20 \mathrm{mM}$ in the mixtures. TSB1 was used as the negative control. The mixtures were incubated overnight at $4^{\circ} \mathrm{C}$. To examine whether the agglutination was calcium dependent, the cells were observed using light microscopy and photographss were taken.

To test the carbohydrate-binding specificity of EALec, $4 \mu \mathrm{L}$ serial dilutions $(80,60$, 50, 40, and $20 \mathrm{mM}$ ) of D-glucose, D-galactose, D-mannose, and mannose-6-P (Sigma) were premixed with $1 \mu \mathrm{L} 100 \mathrm{mg} / \mathrm{mL}$ EALec at room temperature for $1 \mathrm{~h}$. Next, $14 \mathrm{~mL} V$. harveyi suspension $\left(20 \mathrm{mM} \mathrm{Ca}^{2+}\right)$ were added to each of the carbohydrate - CLHd mixtures. The mixtures were stored overnight at $4{ }^{\circ} \mathrm{C}$ before observation.

\section{RESULTS}

\section{Genome organization of the EALec1 gene from E. akaara}

The genome structure of the EALec1 gene of E. akaara was elucidated by comparing the full-length cDNA sequence of EALec1 to the corresponding genomic fragments sequenced. The coding region of this gene consists of $2714 \mathrm{bp}$ and is grouped into 5 exons with 
lengths of 22, 183,152, 122, and $169 \mathrm{bp}$, and 4 introns with lengths of 85, 162, 96, and 1723 bp (Table 2). All exon-intron junctions follow the consensus rule of the splice donor [GT and acceptor sites (AG) for splicing (Figure 1)]. The CRD domain of the EALec1 of E. akaara is encoded by exons 3, 4 and 5 (Figure 2).

Table 2. The introns and exons in the Epinephelus akaara EALec genomic sequence.

\begin{tabular}{lcccc}
\hline EXON & Genomic coordinates & mRNA coordinates & Length & Encoding domain \\
\hline EXON1 & $1-22$ & $1-22$ & 22 & M \\
EXON1 & $108-290$ & $23-205$ & 183 & Col+N \\
EXON3 & $453-604$ & $206-357$ & 152 & N+CRD \\
EXON4 & $701-822$ & $358-479$ & 122 & CRD \\
EXON5 & $2546-2714$ & $480-648$ & 169 & CRD \\
\hline
\end{tabular}

\begin{abstract}
ATGAMOCTCATCAMARCGMGGTAAGTCCATCCTTACACAGTGTCCACAMGTGAGTGTСEGTCACCATGTACOCTCATGTTGTATCTTTACATTCTETCT TCTCACECACOCTG

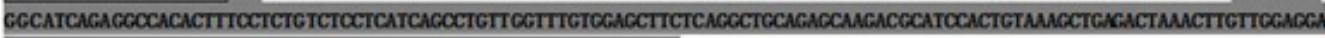

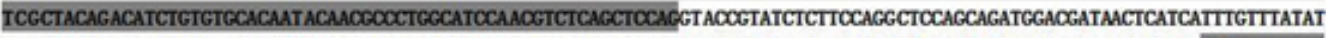

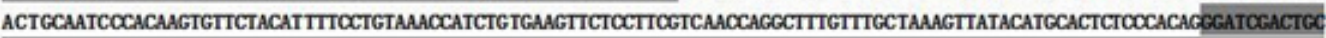

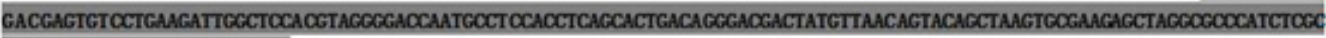

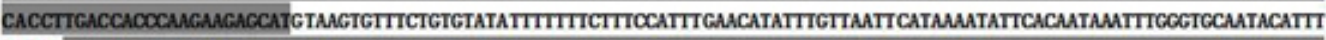

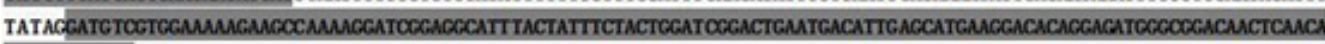
CTTGAAACCTCGTATGTATAAAACAATTAATATCAAAATACTOGTCATGATAACACAACATССTGTAAGTGCTATAAATACOGITTTGGAAACAGOCAGACATGAAAATCAAAACT

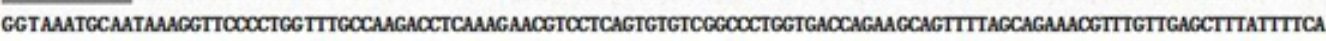

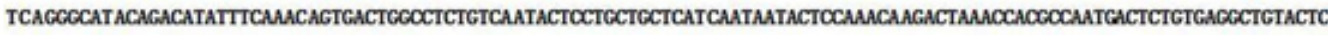

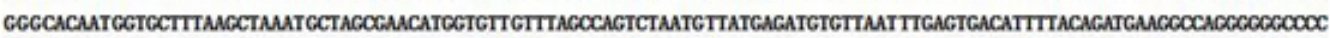

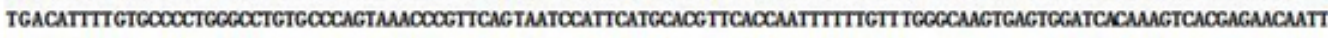

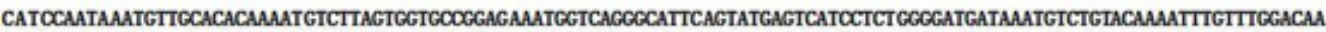

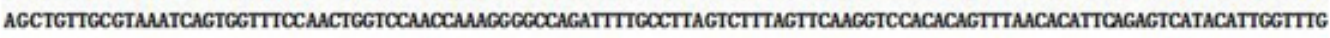

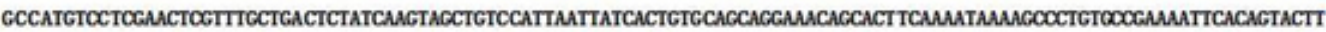

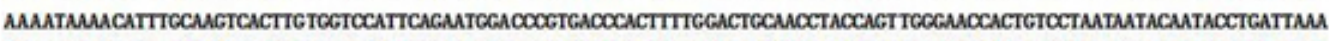
ААСТАСТСАGСТTATTMМИМ

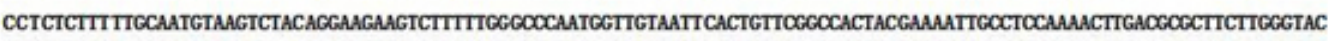

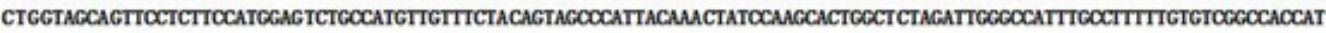

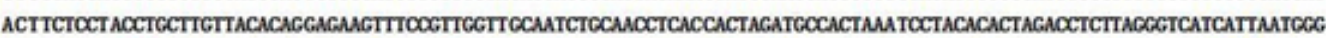

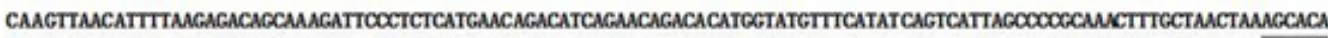

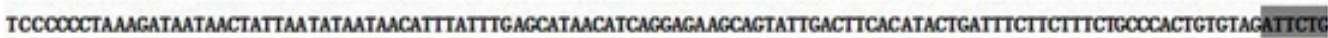

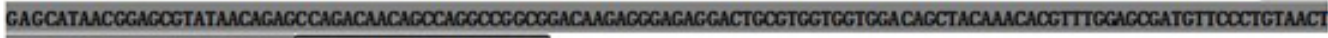
ICATCTATCCOCCANCTGTCACA CGOCCCTACOOCATTCMGTGA
\end{abstract}

Figure 1. The Epinephelus akaara EALec genomic sequence. The sequences with frames are the specific primers, and the shaded ones represent the mRNA sequence.

\title{
The constitutive expression of the EALec1 transcript in different tissues
}

To identify where the EALec1 gene was expressed, RNA analyses were performed with qRT-PCR for 12 tissues including blood, ovary, liver, spleen, muscle, gill, head kidney, intestine, stomach, fin, heart, and brain. The results suggest a broad distribution of constitutive expression. Nevertheless, the EALec1 mRNA was best expressed in the head kidney and spleen, and least expressed in the liver (Figure 3). Based on the SSCP analysis, four genotypes were identified in all the tissues (Figure 4). The four Genbank accession numbers are FJ426399, FJ426400, FJ426401, and FJ426402. 
FJ426399 and FJ426400 have a same-sense mutation. FJ426401 has a mutation that leads to an amino acid substitution, and the mutation in FJ426402 results in an unexpected translation stop (Figure 5). The result showed that there were at least 2 EALec 1 paralogs in the E. akaara genome.

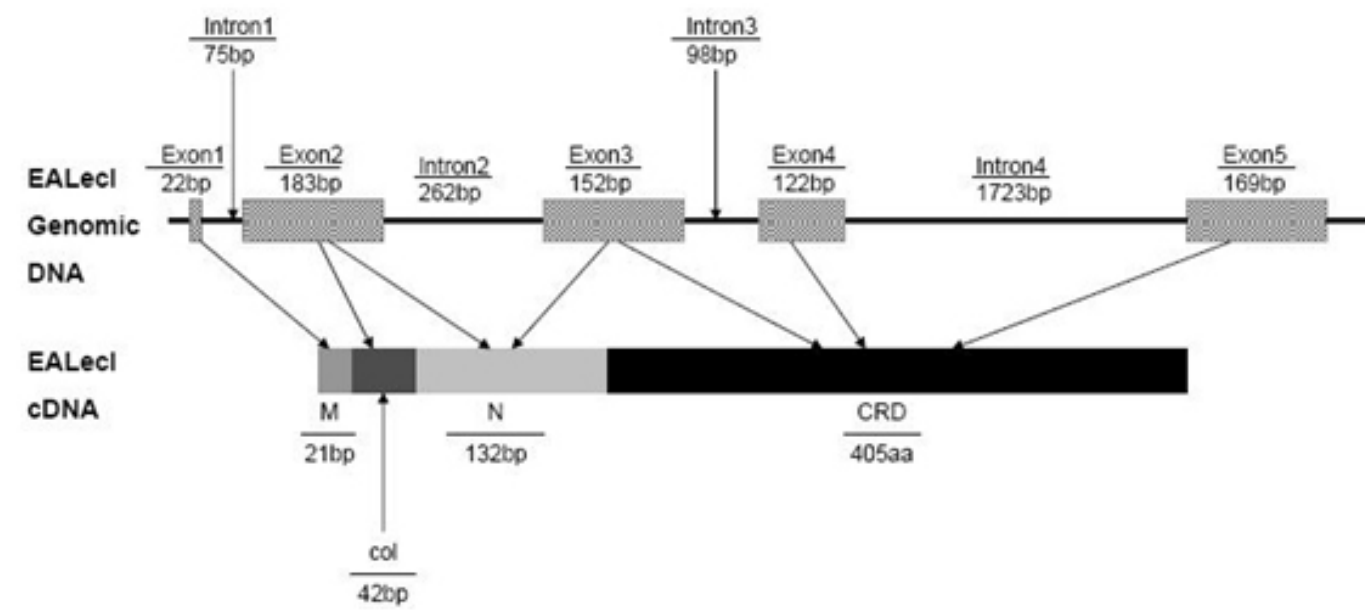

Figure 2. The genomic and cDNA structure of EALec1 of Epinephelus akaara. The exons coding for the proteins are shown as boxes, and the introns are shown as straight lines. The sizes are shown above. $\mathrm{M}=$ initiation methionine; $\mathrm{Col}=$ collagenous region; $\mathrm{N}=$ neck region; $\mathrm{CRD}=$ carbohydrate recognition domain .

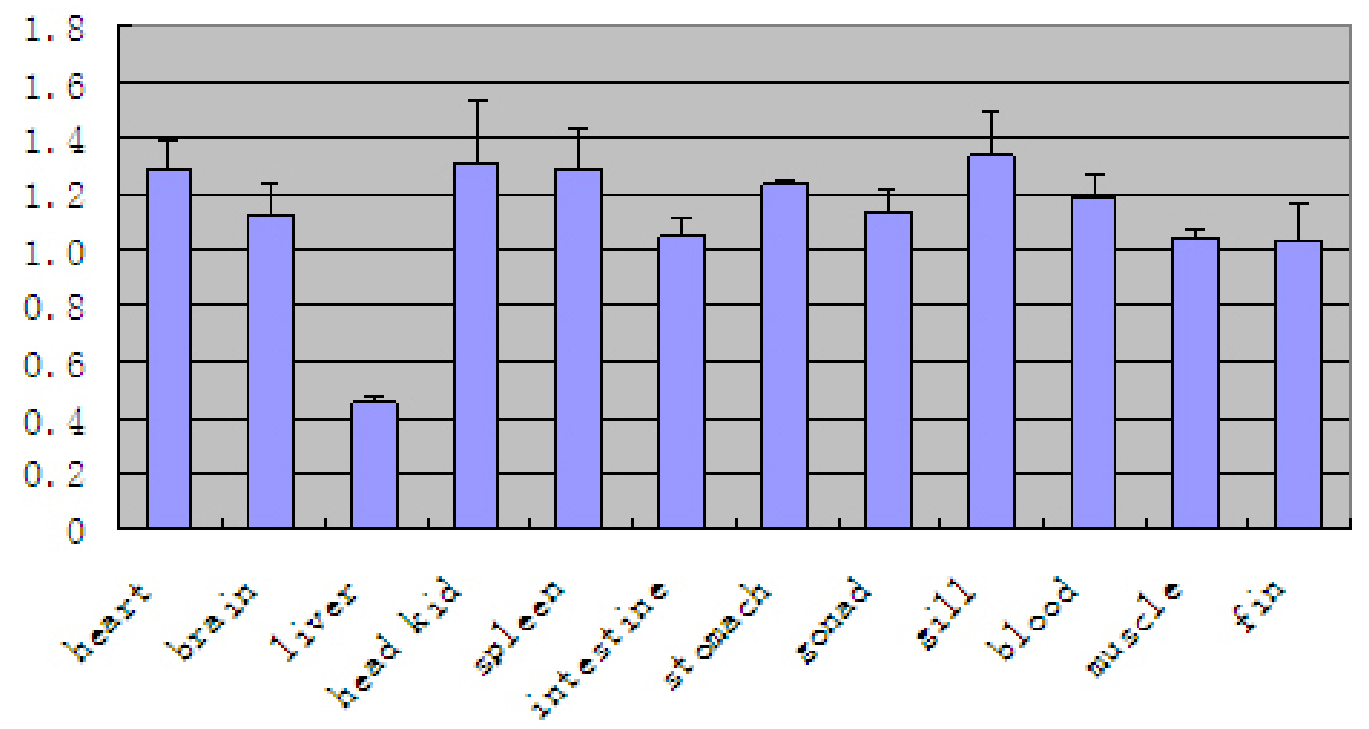

Figure 3. The distribution of the tissues of the EALec1 transcripts that were measured by real-time PCR. 


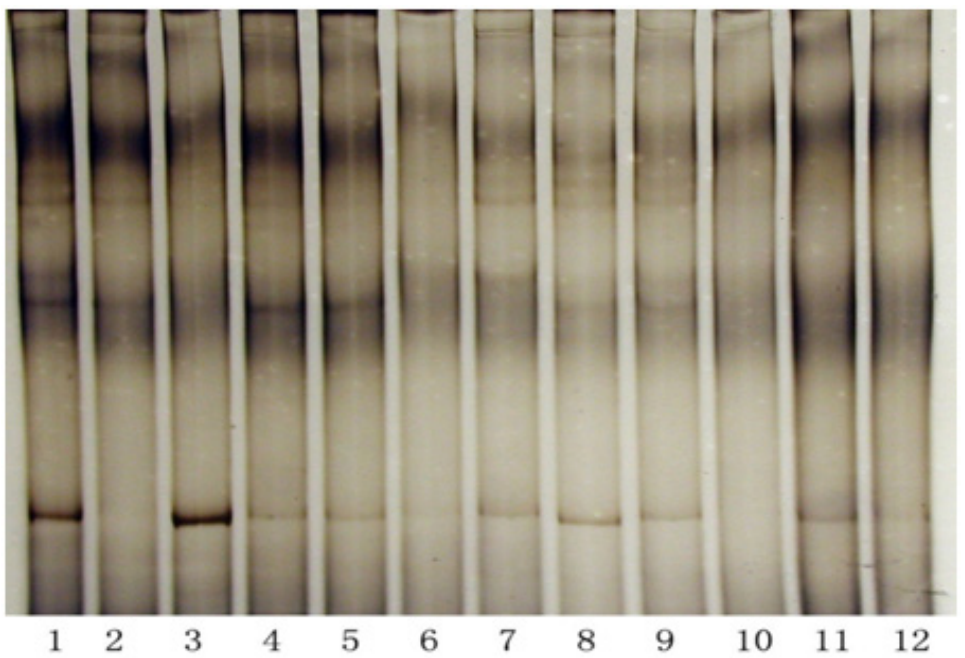

Figure 4. The EALec 1 homologues detected by RT-PCR-SSCP. Lane 1 = fin, lane 2 = muscle, lane $3=$ blood, lane $4=$ gill, lane $5=$ gonad, lane $6=$ stomach, lane $7=$ intestine, lane $8=$ spleen, lane $9=$ head kidney, lane $10=$ liver, lane $11=$ brain, and lane $12=$ heart.

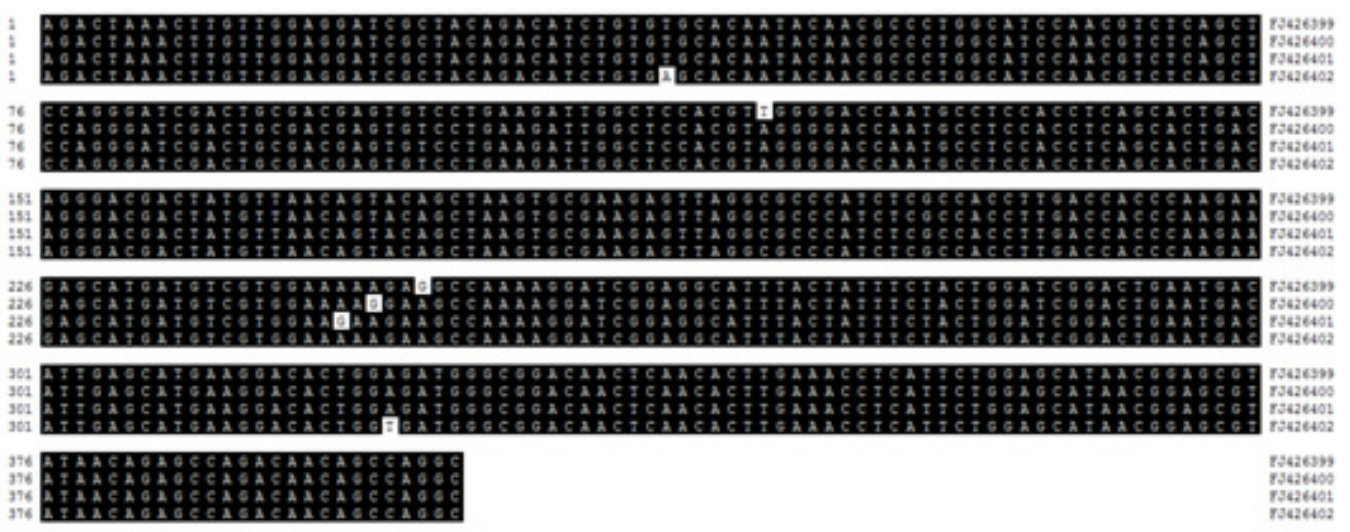

Figure 5. The alignment of 4 EALec1 homologues identified by SSCP.

\section{Recombinant expression of EALec1 in $E$. coli}

The cDNA sequences encoding the complete EALec1 of E. akaara were fused to the His-Tag coding sequence at the 5 '-end. This allows the recombinant protein to be expressed with an additional 6-His-Tag at the C-terminal and to be induced with IPTG. As shown in Figure 6, the recombinant proteins were well induced. In contrast to the cells before induction, a strong band (Figure 6A) was found around $26 \mathrm{kDa}$ in the lysate and the supernatant of the induced cells. The molecular weight was also consistent with the theoretical value of the entire fusion protein of complete EALec1. Each recombinant protein with the His-Tag was purified via Ni-NTA agarose affinity chromatography. The result showed that only one band was distinguishable (Figure 6B). 


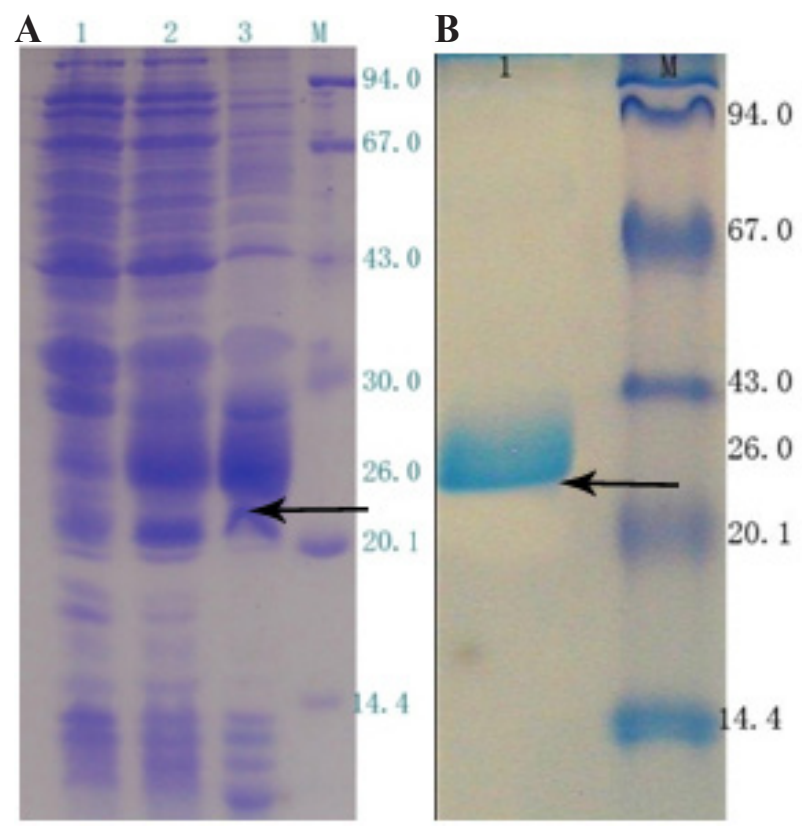

Figure 6. A. SDS-PAGE analysis of recombinant CLHd expressed in Escherichia coli. Lane $1=$ lysate of $E$. coli. BL21(DE3) without induction; lane 2 = recombinant EALec with expression induced by $0.5 \mathrm{mM}$ IPTG in E. coli BL21(DE3) incubated $3 \mathrm{~h}$; lane $3=$ recombinant EALec with expression induced by $0.5 \mathrm{mM}$ IPTG in $E$. coli BL21(DE3) incubated $5 \mathrm{~h}$; lane $4=$ protein marker. The specific band of recombinant CLHd is indicated by an arrow. B. SDS-PAGE analysis of purified recombinant EALec. Lane $1=$ purified recombinant CLHd; lane $2=$ protein marker. The molecular mass of each protein marker band is indicated on the right side of the acrylamide gel.

\section{Bacterial agglutination activity of EALec1}

The Gram-negative pathogenic $V$. harveyi and the Gram-positive non-pathogenic $S$. aureus and $B$. subtilis were used to test the bacterial agglutination activity of EALec1. In 20 $\mathrm{mM} \mathrm{Ca}{ }^{2+}$, agglutination was evident when $V$. harveyi (Figure 7B), S. aureus (Figure 7D) and B. subtilis (Figure 7F) were incubated with EALec1 at a concentration $>10 \mu \mathrm{g} / \mathrm{mL}$. The agglutination of $V$. harveyi (Figure 7A), S. aureus (Figure 7C) and B. subtilis (Figure 7E) was not, however, observed in the absence of $\mathrm{Ca}^{2+}$. This result indicated that EALec1 is a $\mathrm{Ca}^{2+}-$ dependent type lectin.

\section{The carbohydrate-binding specificity of EALec1}

The carbohydrate-binding specificity of EALec 1 was examined using competitive inhibition of various sugars on bacterial agglutination. Table 3 shows the minimum inhibitory concentration of each sugar. When the D-mannose concentration was greater than $50 \mathrm{mM}$, the bacterial agglutination activity of EALec1 was inhibited. In contrast, glucose, galactose and mannose-6-P did not show any inhibitory activity. These results suggested that EALec1 is a mannose-binding type lectin. 

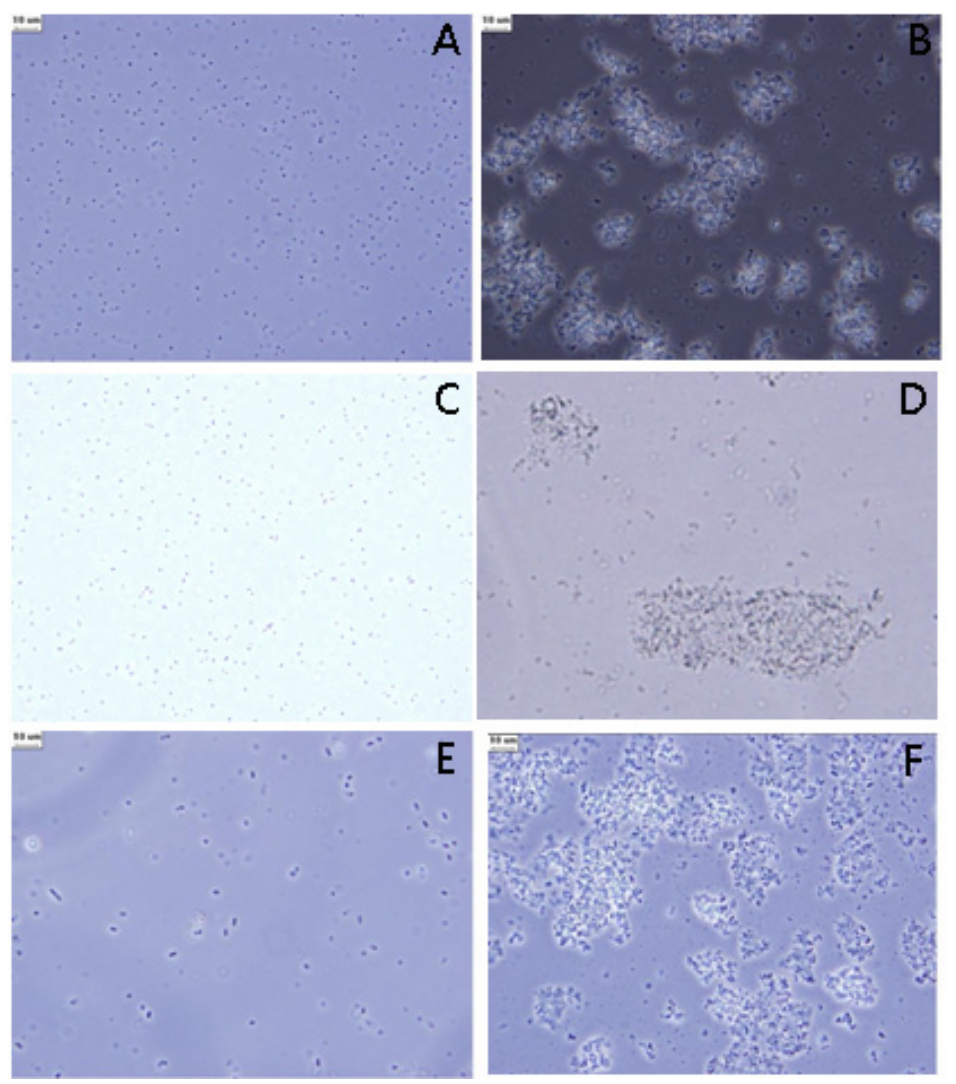

Figure 7. Bacterial agglutination induced by EALec1. A. C. E. control, Vibrio harveyi, Staphylococcus aureus and Bacillus subtilis were incubated in $\mathrm{Ca}^{2+}$-free TBS buffer. B. D. F. V. harveyi, S. aureus and B. subtilis were incubated in $20 \mathrm{mM} \mathrm{Ca}^{2+}$.

Table 3. The inhibition of the bacterial agglutination activity of EALec1 by carbohydrates.

\begin{tabular}{ll}
\hline Saccharide & Minimum inhibitory concentration \\
\hline Mannose & $50 \mathrm{mM}$ \\
Galactose & NI \\
Glucose & NI \\
Mannose-6-P & NI \\
\hline
\end{tabular}

$\mathrm{NI}=$ no inhibitory activity.

\section{DISCUSSION}

In the ascidian genome, nine collectin-like genes have been identified. In comparison to all of the C-type lectin domains of the non-collectin type genes, these C-type lectin domains with collagen form a monophyletic cluster and become a sister group to the vertebrate collectin cluster (Dodds and Matsushita, 2007). Three collectin-like isomers that possess EPN, EPS or EPT-type CRDs have also been identified in Ciona intestinalis. This evidence suggests that the $C$. intestinalis collectin-like genes may share an ancestor with the vertebrate MBL genes 
(Dodds and Matsushita, 2007). Different types of CRD further evolved through gene duplication in fish (Nakao et al., 2006). The EPN-type collectin in lamprey is the earliest vertebrate MBL, whereas GalBL, which has a QPD carbohydrate recognition domain in bony fish, is believed to be a mutated copy from MBL duplication at a certain stage (Vitved et al., 2000; Nakao et al., 2006). In this study, a new C-type collectin with EPD-type CRDs, designated EALec1, was isolated from E. akaara. In the carbohydrate recognition domain, this new collectin seems to be an interim type between MBL and GalBL. Nevertheless, the alignment analyses of the amino acid sequences of MBL (or MBL-like) partial CRD from ascidians to human beings show that EALec1 has more evident insert residues than the MBL or GalBL of primitive vertebrates (Figure 8 ). This suggests that EALec1 likely evolved early as a prototype of the bony fish MBL.
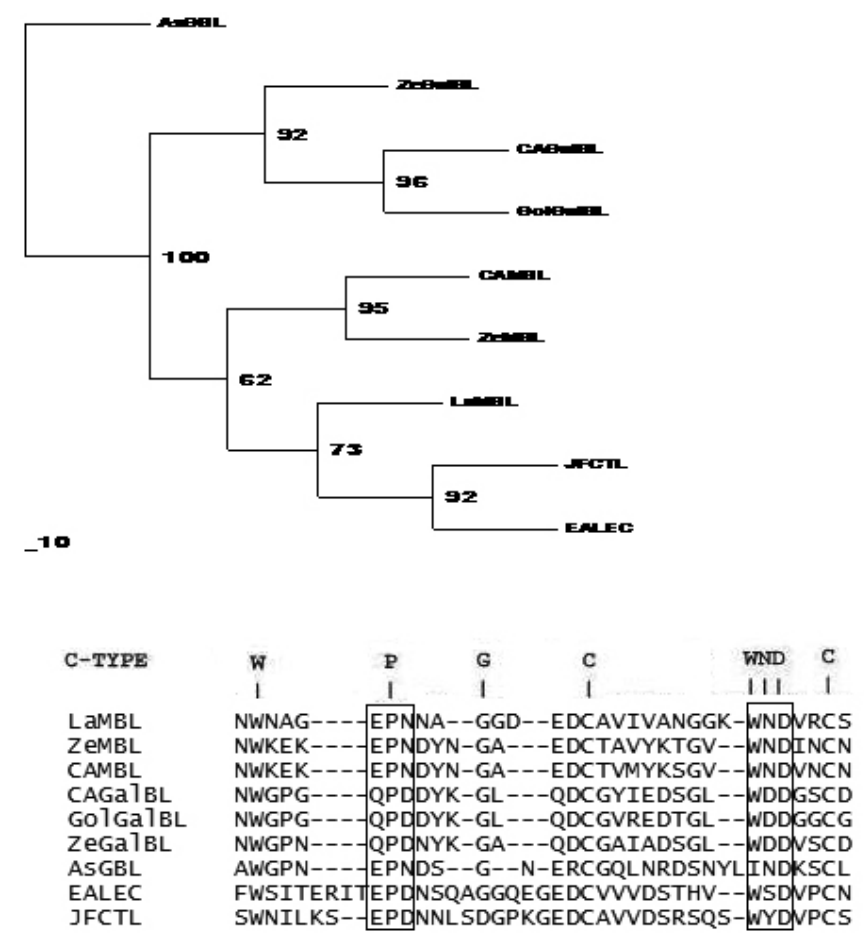

Figure 8. Alignment of the partial CRD amino acid sequences of C-type lectins.

Three copies of the GalBL gene in the Danio rerio genome have been reported (Jackson et al., 2007). All of them were found to comprise 3 exons and to have the same QPD motif in the CRD domain. However, the MBL gene that possesses the EPN motif has only one copy in the D. rerio genome and is composed of 4 exons (Nakao et al., 2006; Jackson et al., 2007). In the present study, the EALec1 gene was found to have multiple copies in the E. akaara genome and is composed of 5 exons (Figure 9). The most remarkable difference between EALec1 and MBL/GalBL in the genomic structure occurs in the first exon. Compared to MBL and GalBL, the first exon in EALec1 lacks a partial collagenous sequence (Gly-X-Y repeats). 
The whole EALec 1 protein has only 4 Gly-X-Y repeats. In contrast, MBL and GalBL have more than 10 repeats in the collagenous region (Thiel, 2007). This apparent lack of the partial collagenous region-encoding sequence in EALec1 could be due to an incomplete assembly of contigs and scaffolds such as with MBL in Takifugu (Nakao et al., 2006). It also implies that EALec1 might have originated from a common ancestor of vertebrate collectin genes, including MBL.
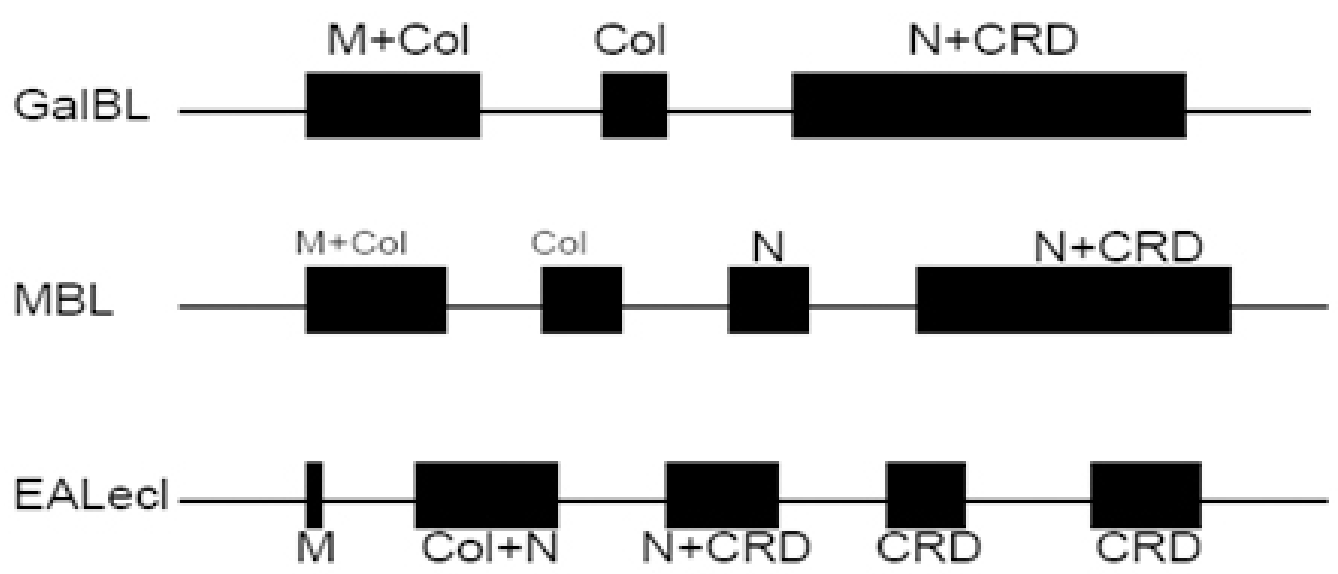

Figure 9. The genomic structure of the three type of collectins. The abbreviations for domain names: M, the initiation methionine; Col, collagenous region; $\mathrm{N}$, neck region; $\mathrm{CRD}$, carbohydrate recognition domain.

MBLs seem to have different expression pattern in different tissues. Two MBL homologues from rainbow trout (Oncorhynchus mykiss) are expressed exclusively in the liver or the spleen (Nikolakopoulou and Zarkadis, 2006). GalBL can be detected in the spleen, liver, gill and intestine in the cyprinidae, gold fish and zebra fish (Vitved et al., 2000). In this study, EALec1 was detected in all 12 tissues examined, which means that expression of this novel C-type lectin was not specific to any tissues of E. akaara, thereby resulting in a broader defensive area than that of MBL.

As a C-type lectin, EALec1 also has a calcium-binding site. It can agglutinate Gramnegative pathogenic $V$. harveyi and Gram-positive non-pathogenic $S$. aureus and B. subtilis in the presence of $\mathrm{Ca}^{2+}$. This study shows that EALec1 has a broad-spectrum bacterial agglutination activity in vitro when compared to some other lectins (Ewart et al., 2001; Zheng et al., 2008; Russell et al., 2008). To our knowledge, this is the first time that a lectin gene from a fish was isolated, recombinantly expressed in E. coli and processed into a bacterial agglutination activity test in vitro. The carbohydrate-binding specificity test demonstrated that EALec1 is a mannose-binding lectin, despite the presence of the EPD-type CRDs. The results also imply that the sequences of the carbohydrate-recognizing sites in the lectin could be flexible in some way to recognize specific carbohydrates.

\section{ACKNOWLEDGMENTS}


Research supported by the Nature Science Foundation of Fujian Province of China (\#2010J01226) and the project of Seed industry innovation and industrialization of Fujian Province of China (the subtopic of grouper).

\section{REFERENCES}

Atkinson AP, Cedzynski M, Szemraj J, St SA, et al. (2004). L-ficolin in children with recurrent respiratory infections. Clin. Exp. Immunol. 138: 517-520.

Boshra H, Li J and Sunyer JO (2006). Recent advances on the complement system of teleost fish. Fish Shellfish Immunol. 20: $239-262$.

Carroll MC and Prodeus AP (1998). Linkages of innate and adaptive immunity. Curr. Opin. Immunol. 10: 36-40.

Dodds AW and Matsushita M (2007). The phylogeny of the complement system and the origins of the classical pathway. Immunobiology 212: 233-243.

Ellis AE (2001). Innate host defense mechanisms of fish against viruses and bacteria. Dev. Comp. Immunol. 25: 827-839.

Endo Y, Nonaka M, Saiga H, Kakinuma Y, et al. (2003). Origin of mannose-binding lectin-associated serine protease (MASP)-1 and MASP-3 involved in the lectin complement pathway traced back to the invertebrate, amphioxus. $J$. Immunol. 170: 4701-4707.

Endo Y, Takahashi M and Fujita T (2006). Lectin complement system and pattern recognition. Immunobiology 211: 283-293.

Ewart KV, Johnson SC and Ross NW (2001). Lectins of the innate immune system and their relevance to fish health. ICES J. Mar. Sci. J. Conseil. 58: 380-385.

Fujita T, Endo Y and Nonaka M (2004a). Primitive complement system-recognition and activation. Mol. Immunol. 41: 103-111.

Fujita T, Matsushita M and Endo Y (2004b). The lectin-complement pathway-its role in innate immunity and evolution. Immunol. Rev. 198: 185-202.

Gaboriaud C, Teillet F, Gregory LA, Thielens NM, et al. (2007). Assembly of C1 and the MBL- and ficolin-MASP complexes: structural insights. Immunobiology 212: 279-288.

Heemstra PC and Randall JE (1993). FAO Species Catalogue. Vol. 16. Groupers of the World (Family Serranidae, Subfamily Epinephelinae), Roma.

Jackson AN, McLure CA, Dawkins RL and Keating PJ (2007). Mannose binding lectin (MBL) copy number polymorphism in Zebrafish (D. rerio) and identification of haplotypes resistant to L. anguillarum. Immunogenetics 59: 861-872.

Janeway CA and Travers P (1997). Immunobiology: The Immune System in Health and Disease, 3rd edn. Current Biology Ltd., London.

Kondo H, Yeu Tzeh AG, Hirono I and Aoki T (2007). Identification of a novel C-type lectin gene in Japanese flounder, Paralichthys olivaceus. Fish Shellfish Immunol. 23: 1089-1094.

Magnadottir B (2006). Innate immunity of fish (overview). Fish Shellfish Immunol. 20: 137-151.

Matsushita M and Fujita T (2002). The role of ficolins in innate immunity. Immunobiology 205: 490-497.

Medzhitov R and Janeway C (2000). Innate immunity. New Engl. J. Med. 343: 338-344.

Miller ME, Seals J, Kaye R and Levitsky LC (1968). A familial, plasma-associated defect of phagocytosis. Lancet 292: 60-63.

Nakao M, Kajiya T, Sato Y, Somamoto T, et al. (2006). Lectin pathway of bony fish complement: identification of two homologs of the mannose-binding lectin associated with MASP2 in the common carp (Cyprinus carpio). J. Immunol. 177: 5471-5479.

Nikolakopoulou K and Zarkadis IK (2006). Molecular cloning and characterisation of two homologues of MannoseBinding Lectin in rainbow trout. Fish Shellfish Immunol. 21: 305-314.

Nonaka M and Smith SL (2000). Complement system of bony and cartilaginous fish. Fish Shellfish Immunol. 10: 215-228.

Pancer Z and Cooper MD (2006). The evolution of adaptive immunity. Annu. Rev. Immunol. 24: 497-518.

Runza VL, Schwaeble W and Mannel DN (2008). Ficolins: novel pattern recognition molecules of the innate immune response. Immunobiology 213: 297-306.

Russell S, Young KM, Smith M, Hayes MA, et al. (2008). Cloning, binding properties, and tissue localization of rainbow trout (Oncorhynchus mykiss) ladderlectin. Fish Shellfish Immunol. 24: 669-683.

Schluter SF, Bernstein RM and Marchalonis JJ (1997). Molecular origins and evolution of immunoglobulin heavy-chain genes of jawed vertebrates. Immunol. Today 18: 543-549.

Sekine H, Kenjo A, Azumi K, Ohi G, et al. (2001). An ancient lectin-dependent complement system in an ascidian: novel lectin isolated from the plasma of the solitary ascidian, Halocynthia roretzi. J. Immunol. 167: 4504-4510.

Takahashi M, Iwaki D, Matsushita A, Nakata M, et al. (2006). Cloning and characterization of mannose-binding lectin 
from lamprey (Agnathans). J. Immunol. 176: 4861-4868.

Thiel S (2007). Complement activating soluble pattern recognition molecules with collagen-like regions, mannan-binding lectin, ficolins and associated proteins. Mol. Immunol. 44: 3875-3888.

Vitved L, Holmskov U, Koch C, Teisner B, et al. (2000). The homologue of mannose-binding lectin in the carp family Cyprinidae is expressed at high level in spleen, and the deduced primary structure predicts affinity for galactose. Immunogenetics 51: 955-964.

Walport MJ (2000). Lupus, DNase and defective disposal of cellular debris. Nat. Genet. 25: 135-136.

Whyte SK (2007). The innate immune response of finfish - a review of current knowledge. Fish Shellfish Immunol. 23: $1127-1151$.

Xu X, Wang J and Su Y (2009). Histopathological studies of Pseudosciaena crocea experimentally infected with Vibrio harveyi. J. Xiamen Univ. (Nat. Sci.) 48: 281-286.

Zapata AG, Torroba M, Varas A and Jimenez AV (1997). Immunity in fish larvae. Dev. Biol. Stand. 90: 23-32.

Zheng P, Wang H, Zhao J, Song L, et al. (2008). A lectin (CfLec-2) aggregating Staphylococcus haemolyticus from scallop Chlamys farreri. Fish Shellfish Immunol. 24: 286-293. 